\title{
Distinct Features of Pepper yellow mosaic virus Isolates from Tomato and Sweetpepper*
}

\author{
Luis C. V. da Cunha ${ }^{1}$, Renato de O. Resende ${ }^{1}$, Tatsuya Nagata ${ }^{2} \&$ Alice K. Inoue-Nagata ${ }^{3}$ \\ ${ }^{1}$ Dep. Fitopatologia, Universidade de Brasília, CEP 70919-970, Brasília, DF; ${ }^{2}$ Biotecnologia Genômica, Universidade \\ Católica de Brasília, CEP 70790-160, Brasília, DF; 'Embrapa Hortaliças, Cx. Postal 218, CEP 70359-970, Brasília, DF, \\ fax (61) 556-5744, e-mail: alicenag@cnph.embrapa.br
}

(Aceito para publicacao em 23/03/2004)

Corresponding author: Alice K. Inoue-Nagata

CUNHA, L.C.V., RESENDE, R.O., NAGATA, T. \& INOUE-NAGATA, A.K. Distinct features of Pepper yellow mosaic virus isolates from tomato and sweetpepper. Fitopatologia Brasileira 29:663-667. 2004.

\begin{abstract}
Determination of virus diversity in the field is vital to support a sustainable breeding program for virus resistance of horticultural crops. The present study aimed to characterize four field potyvirus isolates found naturally infecting sweet pepper (Capsicum annuum) (Sa66 and Sa115) and tomato (Lycopersicon esculentum) (IAC3 and Sa21) plants. Their biological characteristics revealed differences among the isolates in their ability to infect distinct Capsicum spp. and tomato genotypes, and in the severity of symptoms caused by these isolates compared to the infection caused by an isolate of Pepper yellow mosaic virus (PepYMV). Absence of cross-reaction was found among the studied isolates with antiserum against Potato virus $Y$ (PVY). However, all isolates reacted, at different intensities,

with antiserum against PepYMV. All isolates showed high identity percentage (97 to $99 \%$ ) of the amino acid sequence of the coat protein with PepYMV (accession AF348610) and low (69 to 80\%) with other potyvirus species. The comparison of the 3' untranslated region also confirmed this finding with 97 to $98 \%$ identity with PepYMV, and of 47 to $71 \%$ with other potyviruses. The results showed that PepYMV isolates were easily differentiated from PVY by serology and that the host response of each isolate could be variable. In addition, the_nucleotide sequence of the coat protein and 3, untranslated region was highly conserved among the isolates.

Additional keywords: PepYMV, potyvirus, Lycopersicon esculentum, Capsicum annuum.

\section{RESUMO}

Características distintas de isolados de Pepper yellow mosaic virus de tomate e pimentão

A determinação da diversidade de vírus no campo é vital para dar suporte a programas sustentáveis de melhoramento de hortaliças visando a obtenção de resistência genética a esses patógenos. Este estudo objetivou caracterizar quatro isolados de potyvírus encontrados infetando naturalmente plantas de pimentão (Capsicum annuum) Sa66 e Sa115, e tomateiro (Lycopersicon esculentum) IAC3 e Sa21. As características biológicas revelaram diferenças entre os isolados na abilidade de infetar diferentes genótipos de pimentão e tomateiro e na severidade de sintomas causados por estes isolados em comparação com a infecção resultante de um isolado de Pepper yellow mosaic virus (PepYMV). Estudos

sorológicos mostraram ausência de reação cruzada dos isolados estudados com anti-soro para Potato virus Y (PVY). Entretanto, todos os isolados reagiram, em intensidades diferentes, com antisoro para PepYMV. Todos os isolados mostraram alta percentagem de identidade (97 a 99\%) de sequência de amino ácidos da capa proteica com PepYMV (accesso AF348610) e baixa (69 a 80\%) com outras espécies de potyvírus. A comparação da região 3' não traduzida também confirmou esta similaridade, com identidade de 97 a $98 \%$ com PepYMV e de 47 a $71 \%$ com outros potyvírus. Os resultados mostraram que os isolados de PepYMV foram facilmente diferenciados de PVY por sorologia, a resposta de hospedeiros a cada isolado pode ser variável e a sequência de nucletídeos da região terminal 3' foi altamente conservada entre os isolados.
\end{abstract}

The Potyvirus is the largest plant virus genus, with 179 virus species, including 91 definitive and 88 tentative species (Van Regenmortel et al., 2000). The Potato virus $Y$ (PVY) is the type-species of the genus (Hollings \& Brunt, 1981). A broad range of virus strains which differ in their biological and molecular features have been reported within one species. Due to the frequent appearance of strains able to break down the resistance of certain sweet pepper (Capsicum annuum L.) cultivars or hybrids (Nagai, 1993), and the recent

*Part of the dissertation necessary for the M.Sc. degree in Plant Pathology of the first author, Universidade de Brasília (2002). CAPES fellowship report of Pepper yellow mosaic virus (PepYMV) infecting sweet pepper plants in the field (Inoue-Nagata et al., 2002), studies are needed in order to clarify the diversity of the virus, not only in the field, but also among isolates used for screening plant germplasm for virus resistance. This information is crucial for supporting breeding programs and in guiding adequate virus control measures. The current study aimed to characterize at the biological, serological and molecular levels four field potyvirus isolates found naturally infecting sweet pepper and tomato (Lycopersicon esculentum Mill.). Two isolates were collected from infected sweet pepper (Sa66 and Sa115) and two from tomato plants (IAC3 and 


\section{L.C.V. Cunha et al}

Sa21), at São Paulo State. The isolate IAC3 was purified by local lesion in Chenopodium amaranticolor Coste \& Reyn. (to avoid mixed infections) and maintained in tomato plants showing systemic symptoms. The other isolates were generously provided by Sakata Seeds Sudamerica Ltda. The isolates were maintained individually through inoculations in sweet pepper 'Ikeda' or 'Yolo Y', using 0.01 M phosphate buffer, $\mathrm{pH} 7.0$, with $0.01 \mathrm{M}$ sodium sulfite, as inoculation buffer.

The four isolates were mechanically inoculated into a set of differential test plants including some Capsicum spp. and tomato genotypes (Table 1). The results were compared to the isolate Poty1, which belongs to the proposed new species PepYMV (Inoue-Nagata et al., 2002), considered to be the field prevalent potyvirus species infecting sweet pepper. Six plants of each genotype were mechanically inoculated and evaluated for symptom expression. Four plants were inoculated with each virus isolate, and two were mockinoculated as negative controls. The symptom evaluation was carried out up to 30 days-after-inoculation (d.a.i.). The virus presence in symptomatic plants and the occurrence of latent infections were confirmed by Dot-ELISA at 30 d.a.i. Most of the inoculation tests were repeated three times; the Magda cultivar was tested only once.

Serological tests were done using Dot-ELISA and double antibody sandwich ELISA (DAS-ELISA). For the DotELISA test, infected leaves were ground in the presence of PBS buffer $\left(0.07 \mathrm{M} \mathrm{NaCl}, 1 \mathrm{mM} \mathrm{KH}_{2} \mathrm{PO}_{4}, 4 \mathrm{mM}\right.$ $\mathrm{NaHPO}_{4} \cdot 12 \mathrm{H}_{2} \mathrm{O}$ and $1 \mathrm{mM} \mathrm{KCl}$ ). Samples were applied to nitrocellulose membranes (Nitrocell $0.45 \mu \mathrm{m}$, Pharmacia) and blocked with $1 / 2$ PBS and $2 \%$ non-fat powdered milk. Then, the membrane was incubated with polyclonal antiserum against PepYMV (Inoue-Nagata et al, 2002), followed by reaction with goat anti-rabbit IgG phosphatase labeled (Gibco$\mathrm{BRL})$. The enzymatic reaction was developed using detection buffer (100 mM NaCl, $100 \mathrm{mM}$ Tris-base and $5 \mathrm{mM} \mathrm{MgCl}_{2}$, pH 9.5) with $0.165 \mathrm{mg} \cdot \mathrm{ml}^{-1} \mathrm{BCIP}$ and $0.33 \mathrm{mg} \cdot \mathrm{ml}^{-1} \mathrm{NBT}$, as substrates (Bollag \& Edelstein, 1991).

The DAS-ELISA was carried out as described by Clark \& Adams (1977) using $1 \mu \mathrm{g} / \mathrm{ml}$ of polyclonal antiserum against PepYMV (Inoue-Nagata et al, 2002) and PVY produced at Embrapa Hortaliças from a potato (Solanum tuberosum L.) isolate of PVY. The analysis was performed using extract from infected sweet pepper 'Yolo Y' diluted 10, 100 and 1000-fold in PBS-Tween 20. Extract from healthy plants was used as a control.

Amplification, cloning and sequence analysis of part of the genome of the characterized potyviruses were done as follows: anchored reverse transcription-polymerase chain reaction (RT-PCR) was carried out to clone viral cDNA. Total RNA extraction from infected and healthy plants was carried out using Tri Reagent RNA extraction solution (Sigma). Total RNA was used for cDNA synthesis, primed with B1570-Oligo d(T) (5' GGAGAGTCTTGGGCT 10 3'), which was complementary to the polyadenylated tail. The reverse transcription reaction was done using the Moloney murine leukemia virus reverse transcriptase (USB). The PCR was proceeded using the primer PY10 (5, GCAATGCTTGAGTCA TGGGG 3', forward), designed based on Pepper mottle virus (PepMoV) sequence, towards a conserved region in the nuclear inclusion body $\mathrm{b}(\mathrm{NIb})$ cistron, and B1570 (5' GGAGAGTCT TGGGC 3', reverse). The expected fragment size was ca. 1200 base pairs, comprising the coat protein (CP) and 3'-untranslated region (3'-UTR) of

TABLE 1 - Host range and symptom expression of the studied isolates in different pepper (Capsicum annuum) and tomato (Lycopersicon esculentum) genotypes

\begin{tabular}{|c|c|c|c|c|c|}
\hline \multirow{2}{*}{ Species } & \multicolumn{5}{|c|}{ Isolates $^{\mathrm{a}}$} \\
\hline & IAC3 & Sa21 & Sa66 & Sa115 & PepYMV \\
\hline \multicolumn{6}{|l|}{ Capsicum chinense } \\
\hline 'PI 159236' & ns/ns (-) & ns/ns (-) & ns/ns (-) & ns/ns (-) & ns/ns (-) \\
\hline 'PI 152225' & ns/ns (-) & ns/ns (-) & ns/ns (-) & ns/ns (-) & ns/ns (-) \\
\hline \multicolumn{6}{|l|}{ C. annuum } \\
\hline 'Myr-29' & ns/ns (-) & ns/ns (-) & ns/ns (-) & ns/ns (-) & ns/ns (-) \\
\hline 'Ikeda' & $\mathrm{ns} / \mathrm{dvb}(+)$ & $\mathrm{ns} / \mathrm{dvb}(+)$ & $\mathrm{dvb} / \mathrm{dvb}, \mathrm{sm}(+)$ & $\mathrm{ns} / \mathrm{dvb}, \operatorname{lm}(+)$ & $\mathrm{dvb} / \mathrm{dvb}, \mathrm{sm}(+)$ \\
\hline 'Serrano Vera Cruz' & $\mathrm{ns} / \mathrm{ns}(-)$ & $\mathrm{ns} / \mathrm{dvb}(+)$ & $\mathrm{ns} / \mathrm{dvb}(+)$ & $\mathrm{ns} / \mathrm{dvb}(+)$ & $\mathrm{ns} / \mathrm{dvb}(+)$ \\
\hline 'Margarita' & $\mathrm{dvb} / \mathrm{dvb}(+)$ & $\mathrm{lm} / \mathrm{sm}(+)$ & $\mathrm{sm} / \mathrm{sm}(+)$ & $\mathrm{dvb} / \mathrm{dvb}(+)$ & $\mathrm{sm} / \mathrm{sm}(+)$ \\
\hline 'Magali' & $\mathrm{ns} / \mathrm{ns}(-)$ & $\mathrm{ns} / \mathrm{dvb}(+)$ & $\mathrm{ns} / \mathrm{sm}(+)$ & $\mathrm{ns} / \mathrm{lm}(+)$ & $\mathrm{ns} / \operatorname{lm}(+)$ \\
\hline 'Magda' & $\mathrm{dvb} / \mathrm{ns}(+)$ & ns/ns (-) & $\mathrm{dvb} / \mathrm{dvb}, \operatorname{lm}(+)$ & $\mathrm{dvb} / \mathrm{dvb}, \operatorname{lm}(+)$ & $\mathrm{dvb} / \mathrm{dvb}, \operatorname{lm}(+)$ \\
\hline Magali R & ns/ns (-) & ns/ns (-) & $\mathrm{ns} / \mathrm{ns}(-)$ & $\mathrm{ns} / \mathrm{ns}(-)$ & ns/ns (-) \\
\hline \multicolumn{6}{|l|}{ Lycopersicon esculentum } \\
\hline 'Santa-Clara' & ns/ns (-) & $\mathrm{dvb} / \operatorname{lm}, 1 \mathrm{~d}(+)$ & $\mathrm{dvb} / \operatorname{lm}, 1 \mathrm{~d}(+)$ & $\mathrm{ns} / \mathrm{lm}, \mathrm{ld}(+)$ & $\mathrm{ns} / \mathrm{lm}, \mathrm{ld}(+)$ \\
\hline 'Viradoro' & $\mathrm{ns} / \mathrm{ns}(-)$ & $\mathrm{ns} / \mathrm{lm}, \mathrm{ld}(+)$ & ns/ns (-) & $\mathrm{ns} / \mathrm{lm}, \mathrm{ld}(+)$ & $\mathrm{ns} / \mathrm{lm}, \mathrm{ld}(+)$ \\
\hline 'Debora' & $\mathrm{ns} / \mathrm{ns}(-)$ & $\mathrm{ns} / \mathrm{lm}, \mathrm{ld}(+)$ & ns/ns (-) & $\mathrm{ns} / \mathrm{ns}(+)$ & $\mathrm{ns} / \mathrm{ns}(-)$ \\
\hline 'Carmem' & ns/ns (-) & $\mathrm{yvb} / \operatorname{lm}(+)$ & ns/ns (-) & $\mathrm{ns} / \mathrm{ns}(+)$ & $\mathrm{ns} / \mathrm{ns}(+)$ \\
\hline 'Rutgers' & $\mathrm{ns} / \mathrm{lm}, \mathrm{ld}(+)$ & $\mathrm{ns} / \mathrm{lm}, \mathrm{ld}, \mathrm{yvb}(+)$ & ns/ns (-) & $\mathrm{ns} / \mathrm{lm}, \mathrm{ld}(+)$ & ns/ns (-) \\
\hline
\end{tabular}

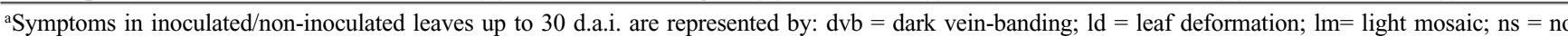
symptom; sm = severe mosaic; yvb = yellow vein-banding. The virus infection was confirmed using Dot-ELISA test, $(+)$ detected, $(-)$ non-detected. 
the potyvirus genome.

The amplified DNA fragments were cloned into the pGEM-T vector (Promega) and the nucleotide sequence determined by automated sequencing using vector primers (T7 and SP6) and two internal primers U335F (5', ATGRTNTGGT GYATHGANAAYGG 3', forward) and U335R (5' GAGCTC GCNGYYTTCATYTGNRHDWKNGC 3', reverse) (Langeveld et al., 1991). The sequences were compiled and analyzed using the package programs DNASIS ${ }^{\circledR}$ (Genetic Systems, HITACHI Software, version 2.6) and the MacVector $^{\mathrm{TM}}$ program 6.5 (Oxford Molecular).

Initially, the four isolates and the isolate Poty 1 (InoueNagata et al., 2002) were compared for reaction on distinct pepper and tomato hosts after mechanical inoculations. This test was carried out on genotypes of two widely used Capsicum chinense Jacquin. introductions, traditional and new tomato and sweet pepper genotypes. The isolates showed significant differences in the host range as well as in symptom expression, after inoculation to several hosts (Table 1). None of the five isolates infected $C$. chinense PI 159236 and PI 152225, C. annuum 'Myr-29' and 'Magali R'. The isolate IAC3 only infected four out of the 14 tested plants (Table 1). The remaining isolates infected 6 (Sa66), 8 (PepYMV), 9 (Sa21) and 10 (Sa115) out of the tested plants.

The isolate Sa21 did not infect the sweet pepper Magda cultivar. This isolate infected all the tested tomato genotypes, which suggests a good adaptation of this isolate for tomato plants. The isolate Sa21 caused severe symptom expression, including mosaic and severe leaf deformation, in all tested tomato genotypes, except for 'Carmen'.

The isolates Sa66, Sa115 and PepYMV, all from sweet pepper, infected the five susceptible $C$. annuum genotypes. This suggests that these isolates were well adapted to sweet pepper species. It was surprising to find high infectivity of isolate Sa115 comparable to $\mathrm{Sa} 21$ in tomato genotypes.

The isolate IAC3 induced severe symptom of leaf deformation and stunting in Nicandra physaloides (L.) Gaertn. and Nicotiana rustica L., when compared with other isolates (data not shown). This suggests that IAC3 could be more adapted to these species than to sweet pepper and tomato genotypes. In $C$. amaranticolor and C. quinoa Willd., the IAC3 isolate induced chlorotic local lesions, whereas the other isolates caused no symptoms in these species (data not shown). Hence, consistent biological differences were observed among the isolates.

Serological tests were performed to compare the isolates. We observed that all four isolates were able to infect sweet pepper 'Yolo Y' with the same severity. Therefore, in an attempt to avoid differences in virus concentration due to differences in severity, DAS-ELISA analysis was carried out using extract from infected sweet pepper 'Yolo Y'. All five isolates positively reacted with PepYMV antiserum. The Poty1 isolate reacted most strongly $\left(\mathrm{abs}_{405 .:} 1.80\right)$, followed by Sa66 $\left(\mathrm{abs}_{405 .:} 1.57\right)$, IAC3 $\left(\mathrm{abs}_{405 .:} 0.80\right)$, Sa115 $\left(\mathrm{abs}_{405 .:} 0.29\right)$ and $\mathrm{Sa} 21\left(_{405 .:} 0.23\right)$. The PVY isolate and the healthy control showed no reaction. All isolates were found to be related to the PepYMV species. Antigen dilutions of 100 and 1000fold showed similar results. A western blot analysis demonstrated that the coat protein of all four isolates was similar in size and showed the same intensity of reaction as PepYMV (data not shown). It was striking to find a great difference on the absorbance readings, repeatedly observed throughout the study.

In order to confirm the identity of the isolates and search for amino acids differences that could explain the distinct serological reactions, we carried out the coat protein and 3'-UTR nucleotide sequencing. The sequence analysis showed a single open reading frame, comprising 1113 nucleotides without the start codon and preceding the polyadenylated tail. Based on comparisons with PepMoV (accession M96425), it was observed that the last six amino acids (a.a.) of the NIb sequence were identical among all the isolates. Therefore, it was inferred that the cleavage site for $\mathrm{NIb}$ and CP was located at the amino acid 76 and 77 (QA). The 3'-UTR was 279 nucleotides long in all isolates, preceding the polyadenylated tail.

The coat protein sequence comprised 278 a.a., with the stop codon located at nucleotides 835 to 837 . The four isolates showed the highest coat protein amino acid identity with PepYMV, varying from 97 to $99 \%$, and among themselves the identity varied from 95 to $97 \%$. The identity with other potyvirus species ranged from 74 to $80 \%$ with PVY-N ('necrotic strain', X12456), 74 to 77\% with Pepper severe mosaic virus (PeSMV, X66027), 71 to $76 \%$ with Sunflower chlorotic mottle virus (SuCMoV, AF255677), 72 to $76 \%$ with PepMoV (M96425), 70 to $73 \%$ with PVY-0 ('common strain', Z70239), and 69-71\% with Potato virus $V$ (PVV, AJ253119) (Table 2). Shukla et al. (1988) and van der Vlugt et al. (1993) observed that the identity of distinct species of the Potyvirus genus varied from 38 to $71 \%$, whereas in strains of the same virus, it varied from 90 to $99 \%$. This indicates that by the $\mathrm{CP}$ amino acid analysis, all studied isolates were classified within the PepYMV species. Although the high identity percentage confirmed that the four isolates belong to the PepYMV species, it could not explain the varying serological reactions. We speculate that virus concentration drops significantly and irregularly after the initial infection. Alternatively, the different absorbance readings could result from minimal amino acid mutations causing significant changes in the protein conformation.

The isolates did not show the triplet 'DAG' in the amino acids sequences, which has been demonstrated to be essential to potyvirus transmission by aphids (Atreya et al., 1991). In a preliminary test, successful transmission of the isolate Sa115 was obtained, suggesting that for this viral species the 'DAG' motif may not be important for aphid transmission.

The 3'-UTR sequence analysis showed a similar result within the PepYMV isolates, which ranged from 94 to $99 \%$ of identity (Table 2). When this region was compared to other potyvirus species, the identity was lower than that of the coat protein. The identity was approximately $70 \%$ with PepMoV, 


\section{L.C.V. Cunha et al}

TABLE 2 - Identity (\%) of the 3'-UTR nucleotide sequence (above the diagonal line) and coat protein amino acid sequence (below the diagonal line), among the studied isolates and the closest potyvirus species

\begin{tabular}{|c|c|c|c|c|c|c|c|c|c|c|c|}
\hline \multirow{2}{*}{ CP ${ }^{3 N T R}$} & \multicolumn{5}{|c|}{ Studied isolates } & \multicolumn{6}{|c|}{ Gene bank sequences* } \\
\hline & IAC3 & Sa21 & Sa66 & Sa115 & PepYMV & SuCMoV & PVV & PepMoV & PeSMV & PVY-O & PVY-N \\
\hline IAC3 & $100^{100}$ & 99 & 96 & 97 & 97 & 65 & 49 & 70 & 47 & 57 & 57 \\
\hline $\mathrm{Sa} 21$ & 95 & $100^{100}$ & 98 & 94 & 98 & 64 & 49 & 70 & 48 & 57 & 58 \\
\hline Sa66 & 97 & 97 & $100^{100}$ & 98 & 97 & 65 & 49 & 71 & 48 & 58 & 58 \\
\hline Sa115 & 97 & 97 & 95 & $100^{100}$ & 98 & 64 & 49 & 70 & 48 & 57 & 58 \\
\hline PepYMV & 99 & 99 & 97 & 98 & $100^{100}$ & 65 & 49 & 71 & 48 & 57 & 57 \\
\hline SuCMoV & 76 & 75 & 71 & 71 & 77 & $100^{100}$ & 49 & 65 & 47 & 62 & 62 \\
\hline PVV & 70 & 69 & 71 & 71 & 71 & 71 & $100^{100}$ & 49 & 60 & 54 & 54 \\
\hline PepMoV & 76 & 73 & 72 & 72 & 76 & 76 & 72 & $100^{100}$ & 47 & 58 & 56 \\
\hline PeSMV & 77 & 74 & 74 & 74 & 77 & 78 & 70 & 72 & $100^{100}$ & 55 & 55 \\
\hline PVY-O & 73 & 70 & 73 & 73 & 73 & 78 & 70 & 73 & 80 & $100^{100}$ & 88 \\
\hline PVY-N & 80 & 74 & 77 & 77 & 80 & 79 & 71 & 73 & 79 & 97 & $100^{100}$ \\
\hline
\end{tabular}

* SuCMoV (Sunflower chlorotic mottle virus, access AF255677); PVV (Potato virus V, access AJ253119); PepMoV (Pepper motlle virus, access M96425); PeSMV (Pepper severe mosaic virus, access X66027); PVY-0 (Potato virus Y 'common strain', access Z70239); and PVY-N (Potato virus Y 'necrotic strain', access X12456).

$65 \%$ with SuCMoV, 58\% with PVY, 49\% with PVV and 48\% with PeSMV. Hence the analysis of the 3'-UTR nucleotide sequence confirmed that the four isolates belong to PepYMV species, according to the criteria suggested by van der Vlugt et al. (1993). The identity rate was high among the four isolates and no special consensus region was found that was correlated with the biological properties or original host specialization.

Regarding the differences observed in the biological properties, it is important to consider that a few nucleotide substitutions on the viral genome may modify the host range, symptom expression and the serological relationship. It is possible that the few amino acid differences observed could be enough to cause the differences in symptoms and host range, but it is more reasonable to assume that other genes may be implicated in these differences in host range. Only a detailed study of the viral genome and the correlated biological property may reveal the importance and need for studying other genes to separate strains within this species.

Finally, important resistance sources were found in swetpepper 'Magali R', 'Myr-29', 'PI 152225' and 'PI 159236' (Table 1), particularly for 'Myr 29', a non-hybrid $C$. annuum cultivar. Screening programs are strongly encouraged for developing PepYMV resistant cultivars in tomato genotypes. Selection of the isolate to be used in screening tests was shown to be crucially important. According ato our results, sweet pepper genotypes would be better evaluated by inoculation with Poty1, Sa66 or Sa115 isolates, while tomato genotypes are more suited to be evaluated by inoculation of $\mathrm{Sa} 21$ or Sa115 isolates.

The PepYMV is an increasing threat to tomato, sweet pepper and chili pepper (Capsicum spp.) growers (InoueNagata et al., 2003). Therefore, the information contained here provides an important insight about PepYMV and its diversity in the field. The PepYMV isolates are easily differentiated from PVY by serology, and the host response of each isolate can be variable. In addition, the isolates showed a high nucleotide identity of the coat protein and 3'-UTR.

\section{ACKNOWLEDGMENTS}

We thank Sakata Seeds Sudamerica Ltda for providing the Sa21, Sa66 and Sa115 isolates. We are grateful to Dr. Antônio Carlos de Ávila and Dr. André Nepomuceno Dusi for helpful discussion and Dr. Maria Esther Noronha de Fonseca for sequencing assistance. This study was sponsored by Embrapa and CNPq.

\section{LITERATURE CITED}

ATREYA, P.B., ATREYA, C.D. \& PIRONE, T.P. Amino acid substitutions in the coat protein result in loss of insect transmissitbility of a plant virus. Proceedings of the National Academy of Sciences USA. 88:7887-7891. 1991. 
BOLLAG, D.M. \& EDELSTEIN, S.J. Protein methods. New York, Wiley-Liss. 1991.

CLARK, M.F. \& ADAMS, A.N. Characteristics of the microplate method of enzime linked immunosorbent assay for the detection of plant viruses. Journal of General Virology 34:475-483. 1977.

HOLlings, M. \& BRUNT, A.A. Potyvirus group. CMI/ AAB Descripitions of Plant Viruses 15 (245). 1981.

INOUE-NAGATA, A.K., FERREIRA, G.B., HENZ, G.P., RIBEIRO, C.S.C. \& ÁVILA, A.C. Occurrence of Pepper yellow mosaic virus - Potyvirus in sweetpepper, pepper and tomato plants in Brazil. Virus Reviews \& Research 8:186-187. 2003. (Resumo)

INOUE-NAGATA, A.K., FONSECA, E.N., RESENDE, R.O., BOITEUX, L.S., MONTE, D.C., DUSI, A.N., DE ÁVILA, A.C. $\&$ VAN DER VLUGT, R.A.A. Pepper yellow mosaic virus, a new Potyvirus in sweetpepper, Capsicum annuum. Archives of virology 147:849-855. 2002.

LANGEVELD, S.A., DORE, J.M., MEMELINK, J., DERKS, A.F.L.M., VAN DER VLUGT, C.I.M., ASJES, C.J. \& BOL, J.F. Identification of potyviruses using the polymerase chain reaction with degenerate primers. Journal of General Virology 72:1531-
1541. 1991.

NAGAI, H. Pimentão, pimenta-doce e pimentas. In: Furlani, M.M. C. \& Végas, G.P. O melhoramento de plantas no Instituto Agronômico. v.1. Campinas, São Paulo. Instituto Agronômico, 1993. pp.276-294.

SHUKLA, D.D., THOMAS, J.E., MCKERN, N.M., TRACY, S.L. \& WARD, C.W. Coat protein of Potyviruses. 4. Comparision of biological properties, serological relationships and coat protein amino acid sequences of four strains of Potato virus Y. Archives of Virology 102:207-219. 1988.

VAN DER VLUGT, R.A.A., LEUNISSEN, J. \& GOLDBACH, R. Taxonomic relationship between distintic Potato virus $Y$ isolates based on detailed comparisons of the viral coat proteins and 3'-nontranslated regions. Archives of Virology 131:361-375. 1993.

VAN REGENMORTEL, M.H.V., FAUQUET, C.M., BISHOP, D.H.L., CARSTENS, E.B., ESTES, M.K., LEMON, S.W., MENLOFF, J., MAYO, M.A., MC GEOCH, D.J., PRINGLE, C.R. \& WICKENER, R.B. Virus Taxonomy - Seventh Report of the International Committe on Taxonomic of Viruses. Academic Press. 2000. 